\title{
THE COMMUNICATIVE PERFORMANCE OF A SEVERELY HEARING-IMPAIRED ADOLESCENT
}

\author{
ANN RUSSELL, B.A. (SP. \& H. TH.) (WTTWATERSRAND) \\ Psychological and Guidance Services, Cape Education Department, Cape Town
}

\section{SUMMARY}

This study describes the communicative performance of a severely hearing-impaired adolescent. The experimenter taught the subject how to play Russian Backgammon. The subject conversed with, and afterwards taught his mother, speech therapist, and a peer how to play the game. Each dyad played the game once. Videotape recordings were made of each dyadic situation. The channels of communication, both verbal and nonverbal, used by cach speaker, were determined. A relational communication coding scheme, involving the analysis of requests and subsequent responses, was applied to the data. Resufts indicate that the hearing-impaired adolescent, though not always able to hold a dominant position in a dyadic situation, was capable of expressing the same types of control as normal adults. Moreover, the types of control expressed varied as a function of each contextual setting. Whenever the subject did hold a dominant position. the combined verbal plus nonverbal channel was his predominant mode of communication. These findings suggest that a sociolinguistic approach provides important information regarding a hearing-impaired adolescent's communicative performance.

\section{OPSOMMING}

Hierdie studie beskryf die kommunikasiegedrag van 'n erg gehoorgestremde adolessent. Die navorser het die proefpersoon geleer om 'n spel te speel. Die adolessent het.met sy moeder, 'n spraakterapeut en 'n jeugdige van dieselfde ouderdom gesels en hulle later geleer hoe om die spel te speel. Elkeen van die tweetal het die spel eenkeer gespeel. Videobandopnames is gemaak van elke tweegesprek. Die verbale en nie-verbale kommunikasiekleë, deur elke spreker gebruik, is vasgestel. 'n Kommunikasie koderingskema, wat die ontleding van versoeke en daaropvolgende response behels, is gebruik om die gegewens te analiseer. Resultate het aangedui dat die gehoorgestremde adolessent alhoewel hy nie altyd 'n dominante posisie gedurende 'n tweegesprek kan handhaaf nie, nogtans instaat was om dieselfde tipe beheer as normale volwassenes, te openbaar. Die tipe kontrole het verskil as 'n funksie van elke situasie. Wanneer die adolessent wel 'n dominante posisie beklee het, was gesamentlike verbale en nie-verbale kommunikasieweë, sy vernaamste kommunikasiewyse. Hierdie bevindinge dui daarop dat ' $n$ sosiolinguistiese benadering belangrike inligting verskaf aangaande 'n gehoorgestremde adolessent se kommunikasiegedrag.

Most research dealing with the language of the hearing-impaired has focused on syntax. Results across all studies indicate a retardation in linguistic performance. ${ }^{1,6,24}$ These findings, however, do not reflect or predict how the hearing-impaired use their language for communication.

Communication is . . . the transmission of a message from one person to another. ${ }^{27}$ Thus, it is an interpersonal, interactive process ... realized, not only through verbal codes, but also through a matrix of complexly integrated coding mechanisms in a communicative context. ${ }^{22}$ The natural method of communication among the congenitally hearingimpaired is by means of signs, and most hearing-impaired parents use 
sign language with their young hearing-impaired children. ${ }^{17}$ Most hearing-impaired children, however, have hearing parents who, traditionally, have been discouraged from using manual communication.

In an attempt to determine the relative effectiveness of oral versus manual methods of communication, most studies ${ }^{7,13}$ have compared hearing-impaired children of hearing-impaired parents, who use a manual method of communication, with hearing-impaired children of hearing parents, who use oral language. It has been found that hearing-impaired children of hearing-impaired parents. who use a manual method have superior communication skills. ${ }^{21}$

Recently, a number of investigators ${ }^{8,26}$ have utilized a sociolinguistic approach to describe the semantic-pragmatic component of language in the spontaneous communication of hearing-impaired preschool children. The results have revealed a clear difference between the development of a linguistic (semantic) and a communicative (pragmatic) ability: the former ability appeared to be delayed whereas the latter was age appropriate.

Sociolinguistic research has investigated the ways in which children talk to adults and to one another. ${ }^{2,16}$ Very little information, however, has been published regarding the ways in which hearing-impaired adolescents communicate. If the goal of education is to prepare them to communicate effectively in society, then information about their communicative abilities is essential.

Adolescence, being the age between 12 and 21 years, ${ }^{23}$ is a period during which the adolescent has to learn appropriate social roles. ${ }^{25}$ Role relationships are implicitly recognized by the way incividuals interact with each other. Mishler ${ }^{19}, 20$ proposes that questionsustained discourse reflects the role relationships between speakers, particularly along the dominance-submission dimension. For example, in hierarchical relationships, such as a teacher-pupil relationship, it is common for the dominant person to control the dialogue by asking questions and issuing commands. ${ }^{5}$ The subordinate person does not have these privileges, but rather . . . 'is expected to respond to the imposed tasks'. 5

Adolescence is a time of flux ${ }^{11}$ and, during this period, an adolescent manifests both dominant and submissive traits in his/her struggle to establish a sense of identity. ${ }^{23}$. Fearing-impaired adolescents, however,-, have been described as "timid"., 18 "-passive", "shy", and ....." "more introvertive and submissive than those with normal hearing". 12 This study represents a sociolinguistic analysis of the communicative performance of a severely hearing-impaired adolescent in three conversational settings: with his mother, his speech therapist, and a peer. In addition, each dyad will be involved in a game of Russian Backgammon: an interpersonal communicative task selected from the literature. ${ }^{10,15}$ The writer will attempt to answer the following questions: How does a severely hearing-impaired adolescent use his/her existing language to communicate? Has a severely hearing- 
impaired adolescent the requisite skills for successful interpersonal interaction? What is his/her style of interaction in a dyadic situation along a dominant-submissive dimension? Can a severely hearingimpaired adolescent express control or authority in a social interaction? If so, in what specific ways is control accomplished? Which channel(s) of communication will be used?

\section{METHODOLOGY}

\section{AIM}

To describe the communicative performance of a severely hearingimpaired adolescent.

A total description of an adolescent's communicative abilities would be so detailed as to defy analysis. For the purposes of this study, therefore, the complexity of this process was reduced by analysing it within a sociolinguistic framework, in which primary emphasis was given to the interrogative units. An interrogative unit has been defined as "three successive utterances": (1) the question, (2) the response from a second speaker, and (3) the confirmation from the initial questioner. ${ }^{19}$.

\section{SUBJECT (S)}

\section{Description}

The $\mathrm{S}$ used in this study was a white, South African, English-speaking, congenitally severely hearing-impaired male, aged 17 years.

The $\mathbf{S}$ was fitted with 2 hearing aids and has had a consistent history of hearing aid usage, as well as speech and hearing therapy, since 18 months of age. The oral method was used extensively and intensively in the home, both parents having normal hearing. Occasionally, however, natural gesture was used to facilitate interpersonal communication.

At 6 years, he was enrolled as a day student at a school for the deaf. He has not failed an academic school year, and his teachers feel that his intelligence falls within the normal range.

Status of the S's communication behaviour at the time of testing hearing.

Pure tone audiometry revealed a fairly flat, severe sensori-neural hearing loss in the S's left ear. The PTA was $87 \mathrm{~dB}$ (ISO 1964). There was no response in his right ear for all frequencies at the limits of the audiometer.

Speech audiometry revealed an aided Speech Reception Threshold of $30 \mathrm{~dB}$ and a speech discrimination score of $76 \%$ at $60 \mathrm{~dB}$.

The S's speech was characterized by a number of inconsistent articulation errors, and therefore his speech was regarded as being fairly intelligible by his speech therapist at the clinic. 
His voice was fairly high-pitched and monotonous with a densasal quality.

His receptive language ability was better than his expressive ability, but both areas were restricted. An analysis of his expressive language revealed an output of predominantly 3 to 4 word utterances; specific syntactic errors related to marking of tense, plurality, and possessives; inconsistently correct determiner and pronoun usage; ellipsis of large segments, inconsistent tense shifting; and poor cohesion. In terms of pragmatics, he was able to use the informing and ritualizing functions, and express his feelings, in certain situations.

\section{PARTICIPANT SELECTION}

Participants were selected in accordance with the following criteria.

a. They were required to be well known to the $S$.

b. English was required to be their home language.

c. None of the participants had played Russian Backgammon before. In accordance with the above criteria, the S's mother (M), speech therapist at school $(\mathrm{T})$, and best friend $(\mathrm{P})$, who also attended the School for the Deaf, were selected. Thus, one participant was selected out of each of the following primary social relationships: parent-child, teacher-pupil, and friend-friend. ${ }^{4}$

\section{PROCEDURE}

(1) The experimenter (E) taught the $S$ how to play a game known as Russian Backgammon.

As far as possible, the $E$ used a verbal plus gestural and/or manipulative channel of communication to describe each item of game-information.

Once the $S$ had been taught how to play the game, the E played the game once with him to observe whether or not he had understood the rules of the game. ${ }^{14}$

(2) The test procedure

The $E$ ushered each dyad, that is, the $S$ and one participant, into a room and they were asked to discuss (i) television watching; (ii) school; (iii) extra-mural; and (iv) holiday activities as naturally as possible. It was suggested that the participant initiate the conversation by asking the $S$ if he had watched "TV last night". Each dyad was told that when they had finished discussing the 4 activities, the $S$ was going to teach the participant how to play a game.

As soon as the instructions had been given to the dyad, the $E$ left the room and began videotaping their.interaction through' a one-way mirror. Using a Sony Video recorder, testing was complete as soon as the dyad had finished playing the game.

The dyadic interactions were evenly spaced over a period of 8 days and all testing took place in the afternoon when the ambient noise level was low.

Each dyadic interaction was orthographically transcribed by the E from the video recordings. 


\section{ANALYSIS OF THE DATA}

The analysis procedure was applied to the entire length of each conversation and explanation of the rules, as well as the first 5 minutes of each game. Approximately 25 minutes was analysed for each dyad.

The channels of communication used by the $S$ and each participant

Rating of the nonverbal aspects of communication used by the $S$ and each participant was done by the $E$ and a qualified speech therapist who was familiar with the informal gesture system used at the School for the Deaf.

The $E$ and the rater independently analysed each utterance. The symbols $\mathrm{V}, \mathrm{G} / \mathrm{M}$, or $\mathrm{VG} / \mathrm{M}$ were written on the transcription sheets next to each utterance to denote whether the verbal (V), gesture and/or manipulative (G/M), or verbal plus gesture and/or manipulative (VG/M) channel of communication had been used. The $E$ and the rater then compared their analysis. Where there were discrepancies, the videotapes were replayed until exact agreement was reached.

The coding and mapping procedures

All questions (and commands) on the transcript sheets were located and marked "Q". Any utterance following a question (or command) was marked " $R$ ", as it might be a response to it. ${ }^{19}$ If the third speaker, in a sequence of 3 successive utterances, was the same person as the questioner, then the third utterance was counted as a confirmation and marked " $C$ ". 19

Nonverbal modes of communication, viz, gesture and/or manipulation of game material which served as questions, responses, or confirmations was also included.

The interrogative units, consisting of successive question-responseconfirmation (Q-R-C) - utterances were then "mapped" on the transcript sheets as follows:

Q T : Who brings you supper?

$<$ R S : We just help ourselves

$\mathrm{C} \mathrm{T}: \mathrm{Oh}$

Sometimes the R- or C-utterance in one interrogative unit (IU) also included a question. This question then initiated a second IU which was connected to the first through the fact of their having this utterance in common. ${ }^{19}$ If the question was through the R-utterance, the connection was referred to as arching; if it was through the C-utterance, it was referred to as chaining. ${ }^{19}$ Arching and chaining were "mapped" on the transcript sheets as follows:

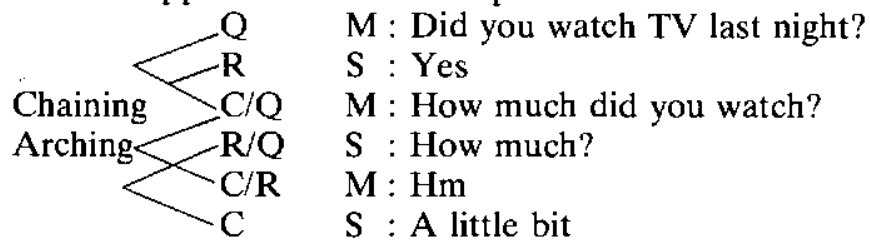

Die Suid-Afrikaanse Tydskrif vir Kommunikasieafwykings, Vol. 28, 1981 
The analysis procedure

The mapped units of dialogue were then analysed. The $\mathrm{E}$ worked through each successive Q-R-C-utterance in 7 scans.

Scan 1: The Q-utterances were analysed in terms of various categories, such as, request for permission, statement in request form, ${ }^{3}$ etc. Each type of question was tabulated and a count made.

Scan 2: Commands were analysed in terms of their being "single" or "multiuttered".

Scan 3: The R-utterances were analysed to ascertain whether the initial question or command was accepted, rejected, or evaded.

Scan 4: The R-utterances were analysed to ascertain whether they contained a question, thereby initiating a second IU, referred to as an arched IU series.

Scan 5: The C-utterances were analysed to ascertain whether they contained a question, thereby initiating a second IU, referred to as a chained IU series.

Scan 6: A chained IU series was further analysed to ascertain whether the R-utterance in the first IU was accepted, rejected, or evaded.

Scan 7: The questions and commands were analysed to ascertain whether they were dominant (D) or submissive (S) bids. A D bid was based on the rationale that the speaker assumed he had the power to make such a demand. An $S$ bid was based on the rationalc that the speaker was dependent upon the responder. ${ }^{3}$

Every D and S bid, response, and IU was tabulated and a count made. The numerical scores for each interaction were then transferred from the transcripts to a score sheet.

Reliability of the coding, mapping, and analysis procedures was obtained for each dyad. The first 5 minutes of each game was analysed for realiability by the $E$ and a qualified speech therapist. Interreliability agreement for these 3 procedures was $73 \%$.

The following areas were then investigated:

(1) The styles of interaction: the ratio of $\mathrm{D}$ or $\mathrm{S}$ bids.

(2) The manner in which control or authority were expressed.

According to Bedrosian and Prutting, ${ }^{3}$ a speaker can express control in any one of the following ways:

(a) when the majority of his bids (either D or S) is accepted;

(b) when the listener is not allowed to respond to the bids due to multi-uttered questions/commands, a statement following the bid, the speaker answering his own question, or when no, résponse is expected;

(c) by the use of arching; and

(d) by the use of chaining only when all of the bids in the IU series are accepted.

The $\mathrm{E}$, therefore, examined the score isheets to ascertain:

(i) the types of control, and

(ii) the frequency with which they were expressed by the $S$ and each participant.

The South African Journal of Communication Disorders, Vol. 28, 1981 
(3) The channels of communication used by the S and each participant. Only 3 different communication channels were considered: a verbal (vocalization only); a gestural (hand movements in the air) and/or manipulative (touching game materials), and a verbal plus gestural and/or manipulative. The S's and each participant's use of these channels was evaluated.

The above procedures were used to analyse the speech used by the $S$ and each participant (a) while conversing; (b) during the S's explanation of the game; and (c) whilst playing the game.

\section{RESULTS AND DISCUSSION OF RESULTS}

(1) THE S'S STYLE OF INTERACTION

Following the previously mentioned mapping and coding procedures, ${ }^{3}$ the frequencies of $\mathrm{D}$ and $\mathrm{S}$ bids, responses, and interrogative units were tallied for the $S$ and all of the participants in each interaction (see Table I for an example of how $S$ interacted with his mother).

\section{Conversational setting}

While conversing with his $\mathrm{M}, \mathrm{T}$, and $\mathrm{P}$, the $\mathrm{S}$ made 0,8 , and $1 \mathrm{D}$ bid, respectively. The $M, T$, and $P$, however, made 24,66 , and $7 D$ bids, respectively. Therefore, it can be said that they held the dominant positions during their conversations with the $\mathrm{S}$.

The above results correspond with those obtained by Mishler, ${ }^{20}$ who found that adult-initiated conversations have a higher number of $D$ bids than those initiated by children.

\section{Explaining the game}

While explaining the game to his $\mathrm{M}$, the $\mathrm{S}$ and his $\mathrm{M}$ both offered $17 \mathrm{D}$ bids. Therefore, neither held the dominant position.

During his explanation of the game to his $\mathrm{T}$ and $\mathrm{P}$, however, the $\mathrm{S}$ offered 19 and $37 \mathrm{D}$ bids, respectively, while $\mathrm{T}$ and $\mathrm{P}$ offered 9 and 3 , respectively. Thus, it can be said that the $S$ held the dominant position during his explanation of the game.

\section{Playing the game}

While playing the game, the $\mathrm{S}$ made more $\mathrm{D}$ bids than any of the participants. Therefore, he held the dominant position each time he played the game.

The overall results indicate that the $S$ held a dominant position in 5 out of 9 settings $(55,5 \%$ of the time), a submissive position in 3 out of 9 settings (33,3\% of the time), and neither a dominant nor a submissive position in one setting $(11,1 \%$ of the time). Thus, by being able to hold both a dominant and a submissive position, the $S$ manifested both dominant and submissive traits. 


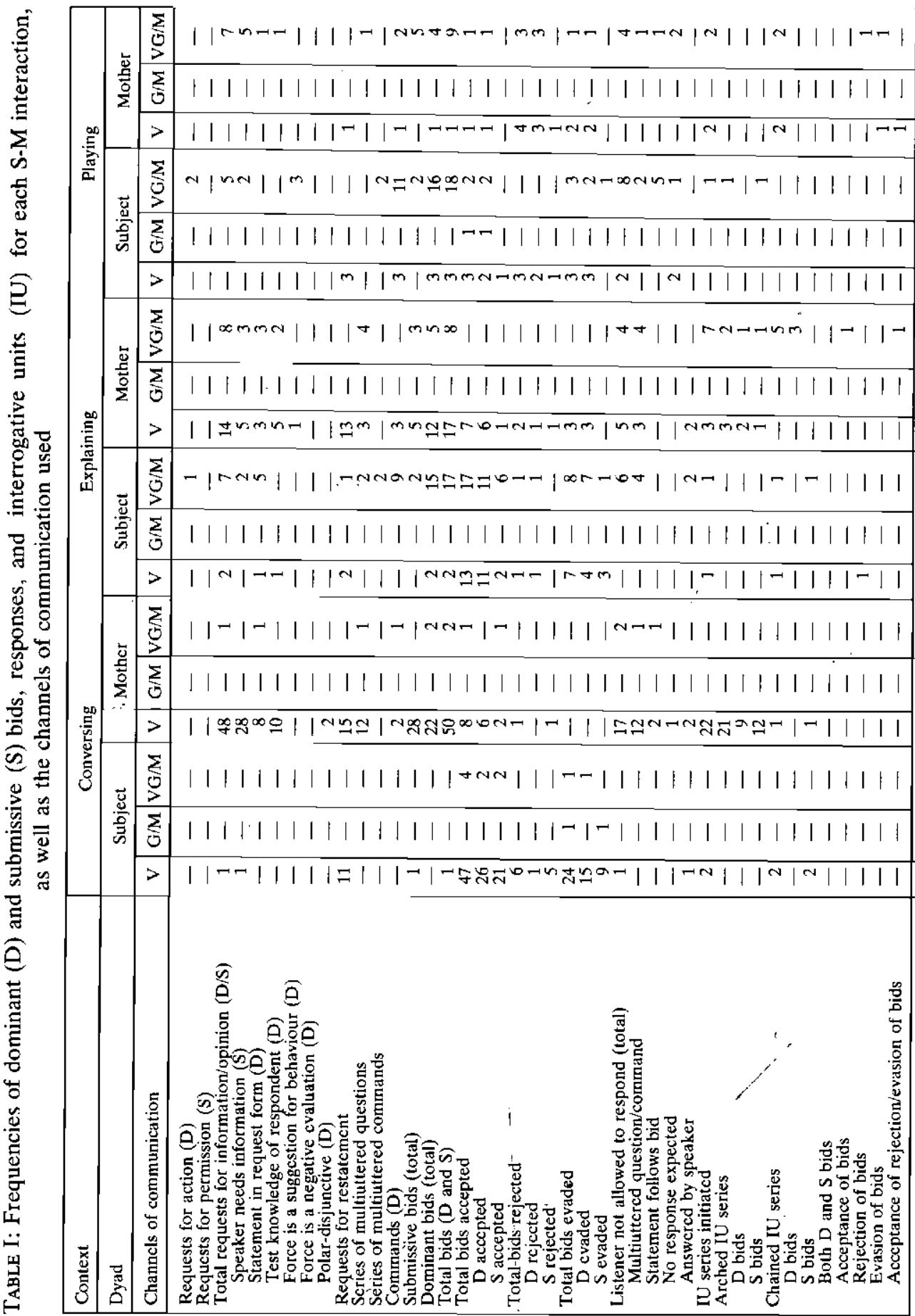

The South African Journal of Communication Disorders, Vol. 28, 1981 
(2) EXPRESSION OF CONTROL

$\mathrm{S}$ expressed all types of control while interacting with his $\mathrm{M}, \mathrm{T}$, and $\mathrm{P}$. The types of control expressed, however, varied as a function of each communicative task. For example, the $S$ used chaining while conversing with all the participants. Mishler ${ }^{20}$ found that adults took control of a conversation through questions that served to chain succeeding units together. Therefore, by using chaining, the $S$ was attempting to take control of each conversation in an adult-like manner.

(3) CHANNELS OF COMMUNICATION USED BY THE S AND EACH PARTICIPANT Table II indicates that while conversing with his $M, T$, and $P$, the $S$ used the $\mathrm{V}$ channel more frequently than the $\mathrm{G} / \mathrm{M}$ or $\mathrm{VG} / \mathrm{M}$ channels. Table II also indicates that the $S$ used the VG/M channel more frequently than the $\mathrm{V}$ or $\mathrm{G} / \mathrm{M}$ channels while explaining and then playing the game. On average, the $\mathrm{S}$ used the $\mathrm{VG} / \mathrm{M}$ channel $84 \%$ of the time.

Table II also indicates that whenever the $S$ held a dominant position, he used the VG/M channel of communication. This indicates the relative efficiency of a combined oral-manual compared to an oral or manual - only mode of communication. ${ }^{21}$

TABLE II: Predominant channels of communication used by the subject and each participant in each contextual setting

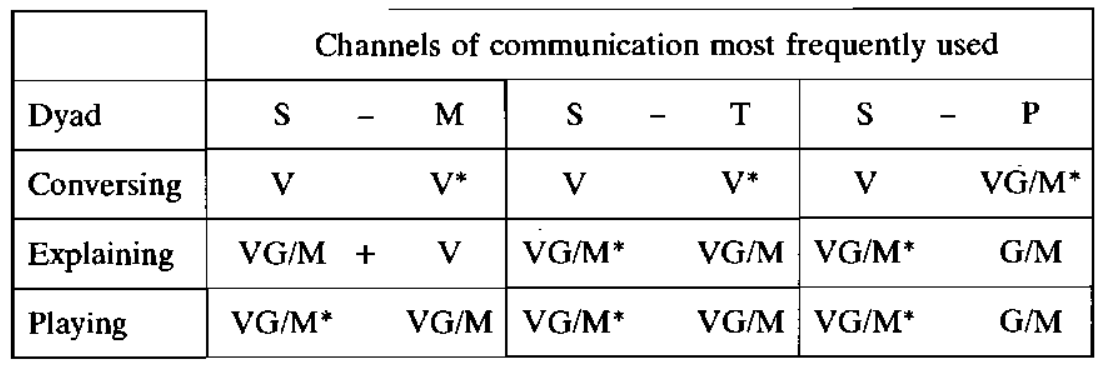

* indicates the dominant speaker in each dyadic interaction

+ indicates that neither speaker held the dominant position in the dyadic situation.

\section{GENERAL DISCUSSION}

The results of this study seem to suggest that a sociolinguistic analysis provides important information regarding a hearing-impaired adolescent's communicative performance. For example, although the S's linguistic abilities were poorer than those of the participants', he was able to use his limited linguistic abilities to hold a dominant position in a social situation.

The fact that he was able to hold both a dominant and a submissive position while interacting with the participants is significant. Firstly, it indicated that he was aware of the social significance of his communica- 
tive performance. Dittmar ${ }^{9}$ found that the average 15 -year-old, with normal hearing, was just as aware of the social significance of his communicative abilities as an adult. Therefore, the S's communicative performance was appropriate for his age. Secondly, Pervin ${ }^{23}$ has stated that adolescents manifest both dominant and submissive traits in their search for a sense of identity. These traits are reflected in the S's style of interaction. Thus, the S's style of interaction also confirms that his communicative performance is age appropriate.

Finally, the overall results of this study reveal a distinct difference between the S's linguistic ability and his communicative performance: the former ability appeared to be restricted whereas the latter was age appropriate.

\section{IMPLICATIONS}

Clinical implications are:

(1) The use of a sociolinguistic analysis as part of a test battery in assessing the communicative behaviour of the hearing-impaired.

(2) The use of a therapeutic programme aimed at improving specific verbal, as well as non-verbal, interpersonal communication skills. Implications for future research lie in:

(1) The determination of the efficacy of this analysis procedure and its applicability to a diversity of language disorders and populations. These include

(a) handicapped children, adolescents, and adults. This procedure has potential for use with the motorically, intellectually, as well as the audiologically impaired.

(b) a large population of hearing-impaired adolescents in an attempt to assess its effectiveness with the mildly, moderately, and profoundly hearing-impaired.

(2) Comparing the communicative performance of

(a) institutionalized and non-institutionalized hearing-impaired adolescents; and

(b) hearing-impaired adolescents of hearing parents with hearingimpaired adolescents of hearing-impaired parents.

\section{REFERENCES}

1. Bamford, J. and Mentz, L. (1979): The Spoken Language of Hearing-impaired Children: Grammar. Chapter 7 in Speechhearing Tests and the Spoken Language of Hearing-impaired Children. Bench, J. and Bamford, J. (Eds.) Academic Press, Inc., London.

2. Bates, E. (1976): Pragmatics and Sociolinguistics in Child Language in Normal and Deficient Child Language. Morehead, D. M. and Morehead, A. E. (Eds.) University Park Press, Baltimore.

3. Bedrosian, J. L. and Prutting, C. A. (1978): Communicative 
Performance of Mentally Retarded Adults in Four Conversational Settings. Jnl. Speech Hear. Res., 21, 79-95.

4. Bell, R. T. (1976): Sociolinguistics: Goals, Approaches, and Problems. St. Martin's Press, New York.

5. Blank, M. and Franklin, E. (1980): Dialogue with Preschoolers: A Cognitively-based System of Assessment. Applied Psycholinguistics, 1, 2: 127-150.

6. Brasel, K. E. and Quigley, S. P. (1977): Influence of Certain Language and Communication Environments in Early Childhood on the Development of Language in Deaf Individuals. Jnl. Speech Hear. Res., 20, 95-107.

7. Brill, R. G. (1960): A Study in Adjustment of Three Groups of Deaf Children. Exceptional Children, 26, 464-470.

8. Curtiss, S., Prutting, C. A., and Lowell, E. L. (1979): Pragmatic and Semantic Development in Young Children with Impaired Hearing. Jnl. Speech Hear. Res., 22, 3: 534-552.

9. Dittmar, N. (1976): Sociolinguistics: A critical Survey of Theory and Application. Edward Arnold.

10. Flavell, J. H., Botkin, P. T., Fry, C. L., Wright, J. W., and Jarvis, P. F. (1968): The Development of Role-taking and Communication Skills in Children. John Wiley \& Sons, New York.

11. Garrison, C. G. (1965): Psychology of Adolescence. Prentice-Hall, Inc., Englewood Cliffs, New Jersey.

12. Goetzinger, C. P. (1978): The Psychology of Hearing Impairment. Chapter 37 in Handbook of Clinical Audiology. 2nd edition. Katz, J. (Ed.) Williams \& Wilkins Co., Baltimore.

13. Goldin-Meadow, S. and Feldman, H. (1975): The Creation of a Communication System: A Study of Deaf Children of Hearing Parents. Sign Language Studies, 8, 224-234.

14. Hoy, E. A. and McKnight, J. R. (1977): Communication Style and Effectiveness in Homogeneous and Heterogeneous Dyads of Retarded Children. American Jnl. of Mental Deficiency, 81, 6: 587-598.

15. Krauss, R. M. and Glucksberg, S. (1969): The Development of Communication: Competence as a Function of Age. Child Development, 40, 255-266.

16. Kretschmer, R. R. and Kretschmer, L. W. (1979): The Acquisition of Linguistic and Communicative Competence: Parent-Child Interactions. Chapter 6 in The Volta Review, 81, 5: 306-322.

17. Meadow, K. P. (1978): The "Natural History" of a Research Project: An Illustration of Methodological Issues in Research with Deaf Children. Chapter 2 in Deaf Children: Developmental Perspectives. Liben, L. S. (Ed.) Academic Press, Inc., New York.

18. Minski, L. and Shepperd, M. J. (1970): Non-Communicating Children. Butterworth and Co., Ltd., London. 
19. Mishler, E. G. (1975): Studies in Dialogue and Discourse: An Exponential Law of Successive Questioning. Language in Society, 4, 31-51.

20. Mishler, E. G. (1975): Studies in Dialogue and Discourse: II. Types of Discourse Initiated By and Sustained Through Questioning. Journal of Psycholinguistic Research, 4, 2, 99-212.

21. Moores, D. F. (1974): Nonvocal Systems of Verbal Behaviour. Chapter 15 in Language Perspectives-Acquisition, Retardation, and Intervention. Schiefelbusch, R. L. and Lloyd, L. L. (Eds.) University Park Press, Baltimore.

22. Muma, J. R. (1978): Language Handbook: Concepts, Assessment, Intervention. Prentice-Hall, Inc., Englewood Cliffs, New Jersey.

23. Pervin, L. A. (1970): Personality: Theory, Assessment, and Research. John Wiley and Sons, Inc., New York.

24. Quigley, S. P., Power, D. J., and Steinkamp, M. W. (1977): The Language Structure of Deaf Children. The Volta Review, 79, 73-84.

25. Schmitt, P. J. and Mercaldo, D. J. (1978): Training Personnel for Hearing-impaired Adolescents. The Volta Review, 80, 5: 359-377.

26. Skarakis, E. A. and Prutting, C. A. (1977): Early Communication: Semantic Functions and Communicative Intentions in the Communication of the Preschool Child with Impaired Hearing. American Annals of the Deaf, 122, 4: 382-391.

27. Stuckless, E. R. (1976): Manual and Graphic Communication. The Volta Review, 78, 4: 96-101. 


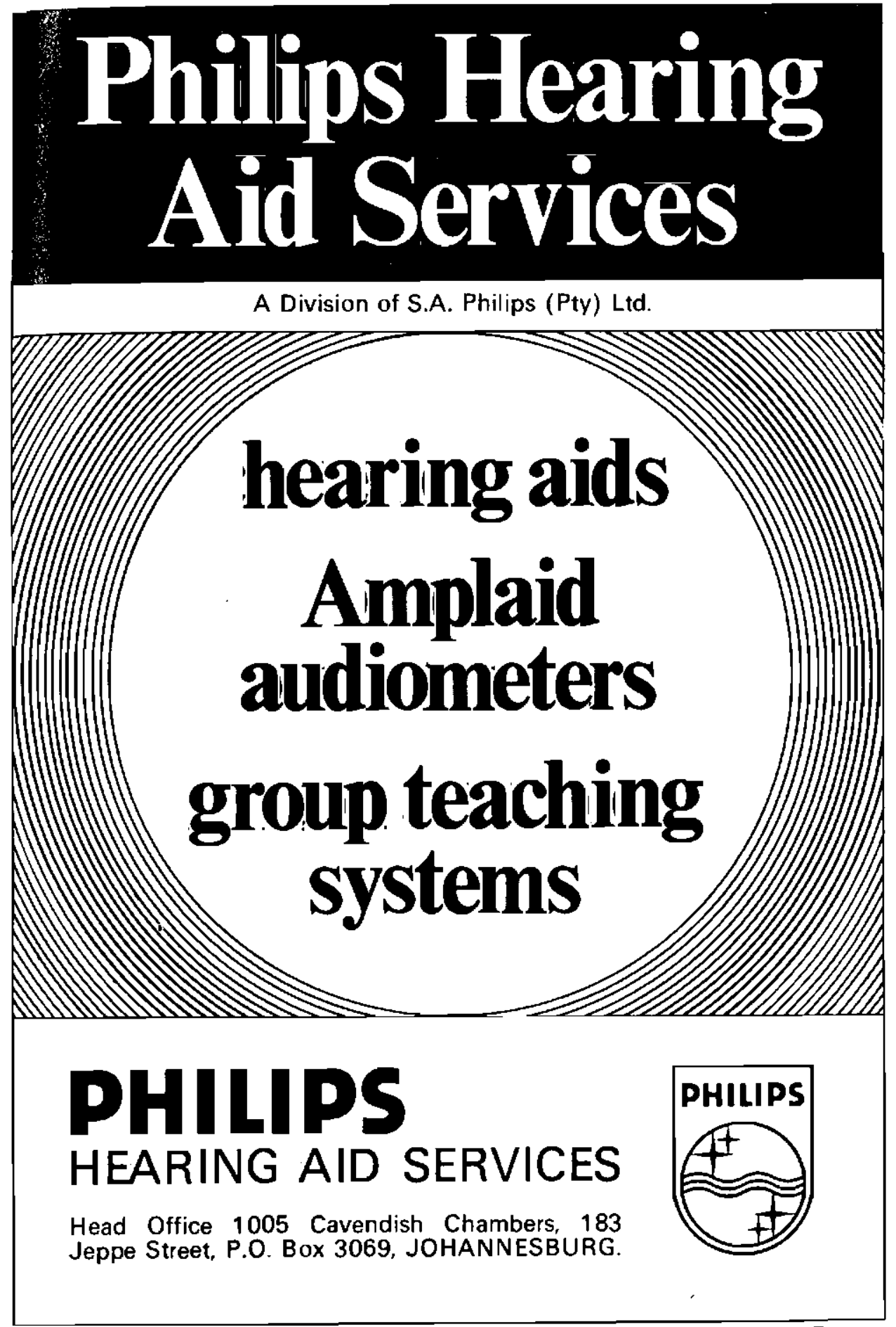

Die Suid-Afrikaanse Tydskrif vir Kommunikasieafwykings, Vol. 28, 1981 